\title{
The influence of sex and gonadectomy on the hypothalamo-pituitary-adrenal axis of the sheep
}

\author{
B J Canny, K A O'Farrell, I J Clarke ${ }^{1}$ and A J Tilbrook
}

Department of Physiology, Monash University, Clayton, Victoria, 3168 Australia

${ }^{1}$ Prince Henry's Institute of Medical Research, PO Box 5152, Clayton, Victoria, 3168, Australia

(Requests for offprints should be addressed to B J Canny)

\begin{abstract}
There is a sex difference in the hypothalamo-pituitaryadrenal (HPA) axis of many species, although there are sparse data on the sheep. In the present study we have compared the HPA axes of intact and gonadectomised adult male and female sheep at the level of the median eminence, pituitary and adrenal glands using a variety of in vitro approaches. The concentration of arginine vasopressin (AVP) was higher $(P<0.01)$ in the median eminence of male than female sheep, and was also elevated by gonadectomy of either sex $(P<0 \cdot 01)$. The concentration of corticotrophin-releasing factor $(\mathrm{CRF})$ in the median eminence did not differ between the sexes, but was also elevated in both sexes following gonadectomy $(P<0.01)$. Anterior pituitary pro-opiomelanocortin mRNA concentrations were higher $(P<0.05)$ in intact male sheep than in intact females, with the levels in gonadectomised animals of both sexes being intermediate. In contrast to this finding, basal ACTH secretion from anterior pituitary cells was higher $(P<0 \cdot 05)$ in cultures derived from female sheep than those from males, but gonadectomy was without effect. There was no effect of sex or gonadectomy on in vitro ACTH secretion in response to AVP, CRF or the combination of AVP and
\end{abstract}

$\mathrm{CRF}$, and in all cases the combination of AVP and CRF generated greater $(P<0 \cdot 0001)$ ACTH secretion than AVP alone. AVP alone was more effective $(P<0 \cdot 01)$ than CRF alone as an ACTH secretagogue. The adrenal glands were larger $(P<0.05)$ in female than male sheep, with no effect of gonadectomy. Basal cortisol production was greatest $(P<0 \cdot 05)$ in cultures of adrenal cells from intact male sheep, though ACTH- and 8BrcAMP-induced cortisol production was greater in the cultures of cells from females $(P=0 \cdot 05)$; there were no effects of gonadectomy. Cultures of adrenocortical cells from male sheep had greater $(P<0 \cdot 05)$ basal cAMP production, but ACTH-stimulated cAMP production did not differ between any of the groups of animals. These findings show a range of differences in the HPA axis of male and female sheep. Furthermore, they suggest that the heightened activity of the axis in the female occurs primarily due to differences at the level of the adrenal gland, and that greater adrenal responsiveness of female animals is due to differences in the latter stages of steroidogenesis, rather than an effect on ACTH signal transduction at its receptor.

Journal of Endocrinology (1999) 162, 215-225

\section{Introduction}

It is well established for various species that there are sex differences in the hypothalamo-pituitary-adrenal axis (HPA), and that these differences occur at virtually all levels of the axis. There are sex-related differences in: the levels of Type I and II glucocorticoid receptors in the hippocampus and hypothalamus (Turner \& Weaver 1985, Carey et al. 1995, MacLusky et al. 1996); the expression of corticotrophin-releasing factor (CRF) and arginine vasopressin (AVP) in the hypothalamus (Vamvakopoulos \& Chrousos 1993, Paulmyer-Lacroix et al. 1996, Viau \& Meaney 1996); the secretion of adrenocorticotrophin (ACTH) from the anterior pituitary (Gallucci et al. 1993); and the size and steroidogenic potential of the adrenal glands (Kitay 1961, Gaskin \& Kitay 1970, Roelfsma et al. 1993, El-Migdadi et al. 1995). It is thought that the differences observed between males and females reflect differential effects of the sex steroids on the HPA axis, as the activity of many proteins which regulate the axis are directly regulated by the steroids and sex steroid receptors are present at many levels of the axis (Hirst et al. 1992, Herbison 1995, Bethea et al. 1996, Madigou et al. 1996). In particular, oestrogen appears to have a stimulatory action on the HPA axis, and hence the axis of the female exhibits generally greater reactivity than that of the male (Handa et al. 1994, Young 1995). Precise physiological or pathological explanations for this increased activity in the female are, however, lacking, but it has been recently hypothesised that the differences in the 
HPA axes may explain sex-related differences in psychological and immunological phenomena (Da Silva 1995, Young 1995).

Although it is clear that the HPA axis of the sheep may be regulated by sex-related factors (Bell et al. 1991, Keller-Wood \& Wood 1991, Pecins-Thompson \& KellerWood 1994, Schwartz \& Rose 1998), few formal comparisons have been made between males and females of this species. Despite the availability of sophisticated in vitro culture techniques for a number of years, these approaches have rarely been used to dissect the differences between the HPA axes of the two sexes of any species. We are also unaware of any studies where in vitro techniques have been used to simultaneously examine the effects of sex and gonadectomy (GDX) on different levels of the HPA axis. Accordingly, our knowledge of the way that sex and sex hormones regulate the HPA axis is limited, and few studies have examined the underlying cellular mechanisms that may be the determining factors. The aim of the current study was to compare the HPA axes of male and female sheep at the level of the median eminence, anterior pituitary and adrenal gland. Furthermore, we examined the effects of long-term GDX in both sexes.

\section{Materials and Methods}

\section{Materials}

Unless otherwise stated, all materials were from Sigma Chemical Co. (St Louis, MO, USA).

\section{Experimental design}

This experiment compared male and female sheep that had either been left intact or had undergone GDX up to 10 months previously. The concentrations of immunoreactive (ir)-AVP and ir-CRF in the median eminence, and pro-opiomelanocortin (POMC) mRNA in the anterior pituitary were measured by RIA and Northern blot analysis respectively. Primary cultures of anterior pituitary and adrenocortical cells were established, and the following parameters were measured: basal and AVP-, CRFand AVP plus CRF-induced ir-ACTH secretion; basal and $\mathrm{ACTH}$ - and 8-BrcAMP-induced cortisol production; and basal and ACTH-induced cAMP production.

\section{Animals}

All animal procedures were conducted with prior institutional ethical approval under the requirements of the Australian Prevention of Cruelty to Animals Act 1986 and the NH\&MRC/CSIRO/AAC Code of Practice for the Care and Use of Animals for Scientific Purposes.

Seven rams and nine ewes of the Romney Marsh breed were used, and the animals were gonad-intact, 3 years of age and weighed between 47 and $69 \mathrm{~kg}$. Animals were held in paddocks at a latitude of $37^{\circ} 49^{\prime}$ south, and had free access to pasture and water. Ten months prior to the experiment, four rams and three ewes underwent GDX using standard surgical techniques, with another two ewes undergoing GDX 6 weeks before the experiment. GDX and tissue collection were conducted during the breeding season for this breed and latitude (Bremner et al. 1984). Between 7 and 10 days prior to the experiment, the animals were transported to the Monash University Department of Physiology Animal House (approximately $50 \mathrm{~km}$ ), where they were kept in individual pens with free access to food and water (ambient temperature $22{ }^{\circ} \mathrm{C}, 12 \mathrm{~h}: 12 \mathrm{~h}$ light:darkness cycle, lights on $0700 \mathrm{~h}$ ). Animals were killed between 0900 and $1000 \mathrm{~h}$, using a lethal i.v. injection of pentobarbitone sodium (Lethobarb, $80 \mathrm{mg} / \mathrm{kg}$; Virbac (Australia), Peakhurst, Australia). At autopsy the median eminence, anterior pituitary gland and the left adrenal gland were removed; the median eminence and a longitudinal hemisection of the anterior pituitary were immediately frozen in liquid nitrogen and stored at $-70{ }^{\circ} \mathrm{C}$ until further analysis, while the other section of the pituitary and the left adrenal gland were collected into ice-cold PBS containing $5 \times 10^{-4} \mathrm{M} \mathrm{MgCl}_{2}$.

\section{Pituitary culture}

Primary culture of anterior pituitary cells was performed using established techniques (Familari et al. 1989). In brief, single pituitary sections (approximately one half of an anterior pituitary) were diced to small cubes (approximately $\left.1 \mathrm{~mm}^{3}\right)$, and treated with trypsin (25 mg/ hemipituitary) (Gibco, Grand Island, NY, USA) and DNAse $(40 \mu \mathrm{g} / \mathrm{ml})$ (Boehringer Mannheim, Mannheim, Germany) in Dulbecco's modified essential medium (DMEM) (JRH Biosciences, Lenexa, KS, USA). After a single cell suspension was obtained, cells were washed in DMEM, containing 10\% foetal calf serum (FCS) (CSL Pty Ltd, Melbourne, Victoria, Australia), $2 \times 10^{-2}$ M Hepes, $100 \mu \mathrm{g} / \mathrm{ml}$ streptomycin and $100 \mathrm{U} / \mathrm{ml}$ penicillin (Gibco), and plated at a density of $2 \times 10^{5}$ cells/well in $1 \mathrm{ml}$ of this medium in 24-well culture dishes (Linbro, Flow Laboratories, McLean, VA, USA). This procedure routinely yielded $7-10 \times 10^{6}$ cells/hemipituitary, with a cell viability of greater than $90 \%$, as assessed by the trypan blue exclusion test. Cells were kept at $37{ }^{\circ} \mathrm{C}$ in a humidified $5 \% \mathrm{CO}_{2}$ incubator for $72 \mathrm{~h}$ prior to treatment. On the morning of treatment, cells were washed extensively with serum-free DMEM containing 0.1\% Polypep and allowed to equilibrate for $1 \mathrm{~h}$ prior to treatment with various concentrations of AVP (Auspep, West Melbourne, Victoria, Australia), ovine CRF (Auspep) or AVP in the presence of CRF $\left(10^{-9} \mathrm{M}\right)$ for $3 \mathrm{~h}$. All treatments were conducted in triplicate. Medium was collected at the end of this period, frozen and stored at $-20{ }^{\circ} \mathrm{C}$ for later 
ACTH analysis. After the medium was removed the plates were frozen on dry ice, then kept for subsequent DNA measurement.

\section{Adrenal culture}

Primary cultures of adrenal cortical cells were obtained using established techniques (Canny et al. 1998). Following removal of the adrenal capsule, the cortex was separated from the medulla, and diced finely. The cortical cells were dispersed in medium 199 (Gibco) containing $2 \times 10^{-2}$ M Hepes, $100 \mu \mathrm{g} / \mathrm{ml}$ streptomycin, $100 \mathrm{U} / \mathrm{ml}$ penicillin and $0 \cdot 1 \%$ Polypep (treatment medium) and $0 \cdot 2 \%$ collagenase I (Worthington, Freehold, NJ, USA) in a waterbath at $37^{\circ} \mathrm{C}$ for $2 \mathrm{~h}$, with gentle agitation. Every 30 min the suspension was passed through a siliconised wide-bore Pasteur pipette for $5 \mathrm{~min}$. The final suspension was put through a Teflon mesh filter $(70 \mu \mathrm{m})$, washed repeatedly in medium 199 containing $2 \times 10^{-2}$ M Hepes, $100 \mu \mathrm{g} / \mathrm{ml}$ streptomycin, $100 \mathrm{U} / \mathrm{ml}$ penicillin, and $10 \%$ FCS, and the cells then plated at a density of $2 \times$ $10^{5}$ cells/well in $1 \mathrm{ml}$ of this medium in 24-well tissue culture plates. The cell viability was greater than $90 \%$ as assessed by trypan blue exclusion. Cells were cultured for $72 \mathrm{~h}$ at $37^{\circ} \mathrm{C}$, in $5 \% \mathrm{CO}_{2}$ in a humidified incubator and were extensively washed with treatment medium prior to treatment. The cells were preincubated for $1 \mathrm{~h}$ prior to treatment with the appropriate experimental reagent for $3 \mathrm{~h}$. All treatments were conducted in triplicate. When cAMP responses to $\mathrm{ACTH}_{1-24}$ (Synacthen; Ciba-Geigy, Pendle Hill, NSW, Australia) were being assessed, $10^{-3}$ M 1-methyl-3-isobutylxanthine was added to the treatment medium. After $3 \mathrm{~h}$ the medium was removed and stored at $-20{ }^{\circ} \mathrm{C}$ until assay. The plates were snap frozen on dry ice, and then stored at $-20{ }^{\circ} \mathrm{C}$ for subsequent DNA determination. Cortisol production from these cultures in response to angiotensin II (AII) and phorbol myristate acetate has recently been reported (Canny et al. 1998).

\section{Extraction of peptides from the median eminence}

AVP and CRF were extracted from the median eminence by homogenisation in $2 \mathrm{ml}$ ice-cold $2 \mathrm{M}$ acetic acid. After sitting on ice for $20 \mathrm{~min}$, the homogenate was spun at $15000 \mathrm{~g}$ for $30 \mathrm{~min}$ at $4{ }^{\circ} \mathrm{C}$. The supernatant was removed, divided into aliquots and lyophilised and stored at $-20{ }^{\circ} \mathrm{C}$ until assay. At this time, an aliquot was taken and resuspended in the appropriate buffer. Extraction efficiency, as assessed by recovery of ${ }^{125}$ I-labelled peptides was greater than $90 \%$.

\section{AVP assay}

AVP was measured using a heterologous double-antibody RIA with a sheep antiserum (S45) raised against AVP conjugated to keyhole limpet haemocyanin. The antiserum was used at a final dilution of 1:240000 in a $5 \times 10^{-2} \mathrm{M}$ PBS containing $0 \cdot 25 \%$ BSA and $0.02 \%$ $\mathrm{NaN}_{3}$, using ${ }^{125}$ I-AVP as tracer and AVP as a standard. The assay demonstrates a crossreactivity of $100 \%$ for lysine vasopressin, and less than $0.01 \%$ for AVP-gly, Arg8 vasotocin and oxytocin, when compared with AVP. Extracts of median eminence reconstituted in assay buffer diluted in parallel to the standard curve for AVP. The sensitivity of the assay was routinely $3.9 \mathrm{pg} /$ tube. Donkey anti-sheep IgG serum (1:800 dilution in $0.5 \mathrm{ml} 2 \%$ polyethylene glycol (PEG)) was used as the precipitating antibody. All the samples were assayed in one assay and the intra-assay coefficient of variation of five quality control standards was $6 \cdot 3 \%$.

\section{CRF assay}

CRF was measured using a heterologous double-antibody RIA with a rabbit antiserum (R3) raised against a peptide (Cys-His-Ser-Asn-Arg-Lys-Leu-Leu-Asp-Ile-Ala- $\mathrm{NH}_{2}$; Chiron Mimotopes, Clayton, Victoria, Australia) conjugated to keyhole limpet haemocyanin via the N-terminal cysteine residue. This peptide is based upon the ten C-terminal amino acids of ovine CRF. The antiserum was used at a final dilution of 1:120000 in $10^{-1} \mathrm{M}$ PBS containing $0 \cdot 5 \% \mathrm{BSA}$ and $0 \cdot 1 \% \mathrm{NaN}_{3}$, using ${ }^{125} \mathrm{I}-\left[\mathrm{Tyr}^{0}\right]-$ ovine CRF (Auspep) as tracer and ovine CRF as standard. The assay crossreacts $100 \%$ with $\left[\mathrm{Tyr}^{0}\right]$-ovine $\mathrm{CRF}$, and less than $0 \cdot 1 \%$ with $\mathrm{ACTH}_{1-39}$, AVP and rat/human CRF. Extracts of median eminence reconstituted in assay buffer diluted in parallel to the standard curve for CRF. The sensitivity of the assay was routinely $3.9 \mathrm{pg} /$ tube. Goat anti-rabbit IgG serum (1:150 dilution in $0.5 \mathrm{ml} 2 \%$ PEG) was used as the precipitating antibody. All the samples were assayed in one assay and the intra-assay coefficient of variation of five quality control standards was $11.9 \%$.

\section{Anterior pituitary $m R N A$ assays}

Total RNA was extracted from the hemipituitary glands as previously described (Mercer et al. 1989) and $25 \mu \mathrm{g}$ total RNA were run for Northern blotting. The RNA was hybridised with a ${ }^{32} \mathrm{P}$-labelled ovine POMC probe (van der Pavert et al. 1997). The RNA was also hybridised with a ${ }^{32}$ P-labelled glyceraldehyde 3-phosphate dehydrogenase GAPDH probe and the expression of the POMC mRNA was standardised against the density of the GAPDH mRNA probe using laser densitometry.

\section{ACTH assay}

ACTH was measured using a heterologous doubleantibody RIA with a rabbit antiserum (R7) raised against $\mathrm{ACTH}_{1-24}$ conjugated to keyhole limpet haemocyanin. This antiserum was used at a final dilution of 1:80 000 in 
a buffer containing $5 \times 10^{-2} \mathrm{M}$ Tris- $\mathrm{HCl}, 5 \times 10^{-4} \mathrm{M}$ EDTA, $10^{-2} \mathrm{M}$ n-ethyl maleimide, 2\% PEG, 0.01\% Triton X-100, $0 \cdot 2 \%$ gelatine, $\mathrm{pH} 7 \cdot 4$, using ${ }^{125} \mathrm{I}-$ $\mathrm{ACTH}_{1-39}$ as tracer and $\mathrm{ACTH}_{1-39}$ as standard. The sensitivity of the assay was routinely $2 \mathrm{pg} \mathrm{ACTH} \mathrm{Al}_{1-39} /$ tube. The antiserum crossreacts $500 \%$ with $\mathrm{ACTH}_{1-24}$, $10 \%$ with POMC, $5 \cdot 2 \%$ with CLIP $\left(\mathrm{ACTH}_{18-39}\right)$ and less than $0 \cdot 1 \%$ with $\alpha$-melanocyte-stimulating hormone $\left(\mathrm{ACTH}_{1-13} \cdot \mathrm{NH}_{2}\right)$ and $\beta$-endorphin, when compared with ACTH $_{1-39}(100 \%)$. Goat anti-rabbit $\operatorname{IgG}$ serum (1:150 dilution in $0.5 \mathrm{ml} \mathrm{2 \%} \mathrm{PEG})$ was used as the precipitating antibody. Medium from anterior pituitary primary culture diluted in parallel to the standard curve. All samples were assayed in duplicate, and the assay had intra- and interassay coefficients of variation of 5.6 and $8 \cdot 7 \%$ respectively $(n=7)$.

\section{cAMP assay}

Following freezing of the cells, cAMP was extracted using acid/ethanol $\left(10^{-2} \mathrm{M} \mathrm{HCl}\right.$ in $95 \%$ ethanol). The cAMP RIA was performed as described by Marley et al. (1991) with the exception that the bound cAMP was separated utilising a second antibody (goat anti-rabbit) at 1/150 dilution in $2 \%$ PEG in a $4{ }^{\circ} \mathrm{C}$ overnight incubation, followed by centrifugation $\left(3000 \times \boldsymbol{g} 4{ }^{\circ} \mathrm{C}, 30 \mathrm{~min}\right)$, aspiration and the pellet counted using a Packard Bell $\gamma$-counter. The sensitivity of the assay was routinely less than $5 \mathrm{fmol} /$ tube, the $\mathrm{ED}_{50} 133.9 \pm 9 \cdot 4 \mathrm{fmol} /$ tube $(n=6)$ and the intra- and interassay coefficients of variation were $8 \cdot 6 \%(n=10)$ and $9 \cdot 8 \%(n=6)$ respectively.

\section{Cortisol assay}

Cortisol production by adrenal cultures was measured by RIA as previously described (Bocking et al. 1986), with the exception that samples were not extracted as medium alone did not interfere with the assay. In brief, samples were assayed in duplicate using $\left[1,2,6,7-{ }^{3} \mathrm{H}(\mathrm{N})\right]$ cortisol (10 000 c.p.m., Amersham, Boston, MA, USA) and a sheep antiserum raised against 4-pregen-11 $\beta, 17 \alpha$, 21-triol-3,20-dione-21-acetate 3 CMO-BSA (\#3368, donated by Dr R I Cox, CSIRO, NSW, Australia). Bound radioactivity was separated following the addition of $20 \%$ PEG and centrifugation (1800 $\mathrm{g} 15 \mathrm{~min}$ ), and counted by liquid scintillation counting using a Beckman $\beta$-counter. The crossreactivity of various steroids (relative to cortisol) are as follows: cortisone (20.5\%), $17 \alpha$-hydroxyprogesterone $(3 \cdot 9 \%)$, corticosterone $(1 \cdot 0 \%)$, progesterone $(0 \cdot 6 \%)$ and 11-deoxycortisol $(<0 \cdot 1 \%)$. The sensitivity of the assay was $2 \cdot 1 \pm 0 \cdot 1 \mathrm{ng} / \mathrm{ml}(n=6)$ and the intra- and interassay coefficients of variation were 9.9 and $13 \cdot 8 \%(n=6)$.

\section{DNA and protein assays}

DNA was extracted from the culture plates by sonication for $15 \mathrm{~min}$ in $2 \mathrm{M} \mathrm{NaCl}, 2 \times 10^{-3} \mathrm{M}$ EDTA,
$5 \times 10^{-2} \mathrm{M} \mathrm{Na}_{2} \mathrm{PO}_{4}$ buffer. The extracts were measured using the fluorochrome Hoechst 33258 at a concentration of $0 \cdot 11 \mu \mathrm{g} / \mathrm{ml}$ as previously described (Labarca \& Paigen 1980). The interassay coefficient of variation was $12 \cdot 6 \%$ $(n=7)$. Median eminence protein content was determined using a BioRad (Hercules, CA, USA) assay, with BSA as a standard.

\section{Statistics}

CRF and AVP concentrations were corrected for the protein concentration of the median eminence, while ACTH secretion and cortisol and cAMP production by pituitary and adrenal cultures, respectively, were corrected for DNA content of the cells. In all cases, the results were compared using a multifactorial ANOVA procedure, with sex, GDX and the interaction term sex by GDX as main factors, with an error term of animal effect nested within sex and GDX. Data were analysed following assessment of homogeneity of variances by Bartlett's and Cochrane's tests; where necessary, data were log or square root transformed prior to analysis. A repeated measures procedure was used for the in vitro secretion studies. As significant between-animal effects were present in all analyses involving agonist-induced secretion in vitro, secretion was expressed as a ratio of basal secretion for that culture. In all cases results are expressed as means \pm s.E.M., and a comparison of the four groups is presented. Differences between individual means were, however, not determined unless a statistically significant interaction between the main factors (sex and GDX) was present. A probability level of $5 \%$ was considered significant.

\section{Results}

\section{Hypothalamus}

The concentrations of ir-AVP and ir-CRF in the median eminence of gonad-intact and GDX male and female sheep are shown in Fig. 1. Concentrations of ir-AVP were higher $(P<0 \cdot 01)$ in the median eminence of male sheep than in female sheep (Fig. 1A), and were also elevated $(P<0 \cdot 01)$ in both sexes following GDX (Fig. 1A). In contrast, the concentrations of ir-CRF were similar in the median eminence of male and female sheep (Fig. 1B), but there was a significant elevation $(P<0 \cdot 01)$ in the concentration of the peptide following GDX of both sexes (Fig. 1B).

\section{Anterior pituitary}

The levels of the mRNA for POMC, relative to that of GAPDH, in the anterior pituitaries of intact and GDX male and female sheep are shown in Fig. 2. There was a 


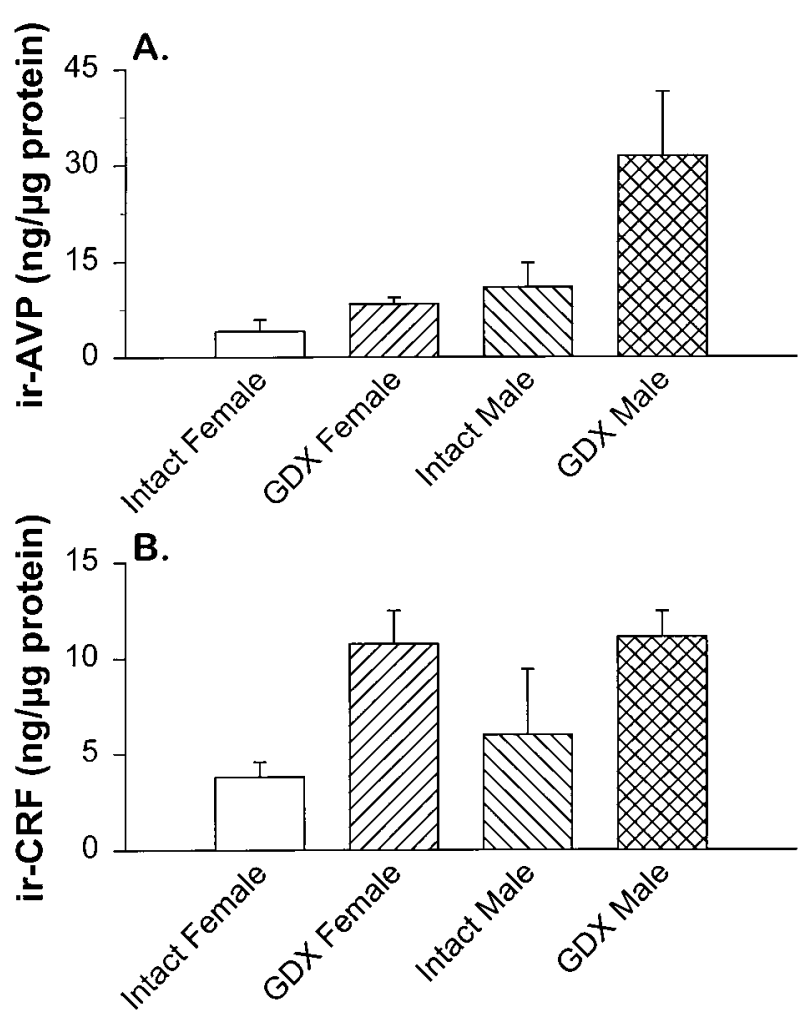

Figure 1 The concentration of ir-AVP (A) and ir-CRF (B) in the median eminence of intact female $(n=4)$, GDX female $(n=5)$, intact male $(n=3)$ and GDX male $(n=4)$ sheep. ir-AVP and ir-CRF concentrations were higher $(P<0 \cdot 01)$ in GDX than intact sheep of both sexes, while ir-AVP concentrations were higher $(P<0 \cdot 01)$ in male than in female sheep.

significant $(P<0 \cdot 05)$ interaction between the sex and GDX with respect to POMC expression, such that the expression was higher $(P<0.05)$ in intact males than intact females, with that of GDX animals of both sexes being intermediate between, and not different from either of the gonad-intact groups.

Basal secretion of ir-ACTH in vitro, after correction for DNA content of the cultures, was higher $(P<0.05)$ in cultures of cells obtained from female sheep when compared with those from males (Table 1); there was, however, no effect of GDX. Secretion of ir-ACTH in response to $\mathrm{CRF}\left(10^{-11}-10^{-7} \mathrm{M}\right.$, Fig. 3A), AVP $\left(10^{-11}\right.$ $10^{-7} \mathrm{M}$, Fig. 3B) and AVP $\left(10^{-10}-10^{-7} \mathrm{M}\right)$ in combination with CRF $\left(10^{-9} \mathrm{M}\right.$, Fig. 3C) was determined relative to basal secretion in each culture. Following this correction, there were no effects of the sex or gonadal status of the animal from which the culture was derived on ir-ACTH responses to any treatment. For each treatment (CRF or AVP alone, and AVP plus CRF), there was a significant $(P<0 \cdot 01)$ concentration effect of the treatment. AVP alone was more effective $(P<0 \cdot 01)$ than $\mathrm{CRF}$ alone in inducing ir-ACTH secretion (Fig. 3A and

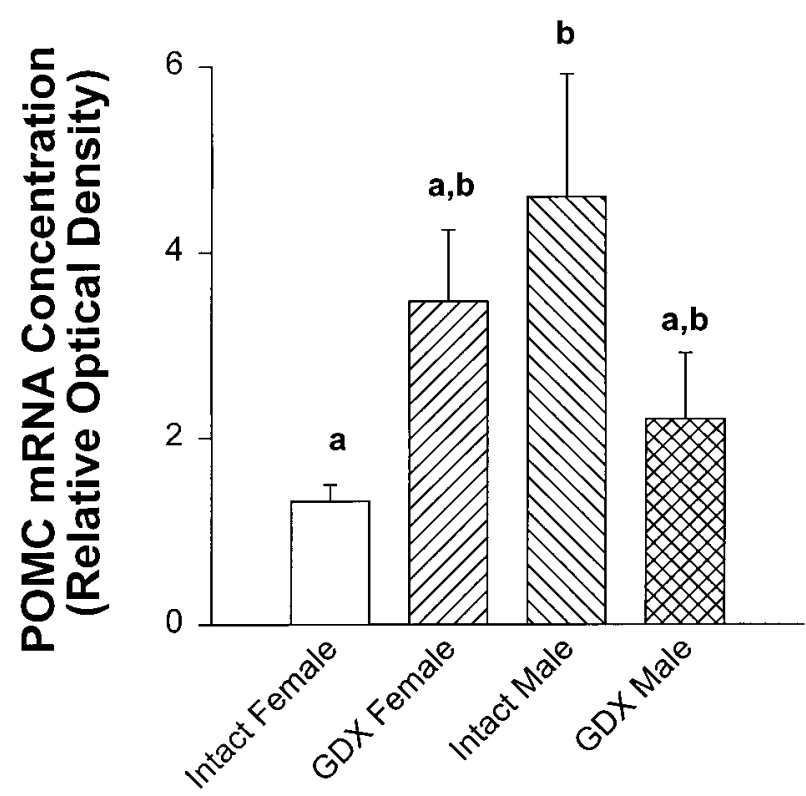

Figure 2 Levels of expression of mRNA for POMC in the anterior pituitary gland in intact female $(n=4)$, GDX female $(n=5)$, intact male $(n=3)$ and GDX male $(n=4)$ sheep. The relative optical density was determined by laser densitometry after correction for the intensity of hybridisation of a probe for mRNA of GAPDH. Bars which do not share a letter (a or b) are significantly $(P<0 \cdot 05)$ different from each other.

B), with the combination AVP plus CRF being more effective $(P<0 \cdot 001)$ than either peptide alone (Fig. 3C). This hierarchy of potencies was not affected by sex or GDX.

\section{Adrenal gland}

The adrenal glands were proportionately heavier $(P<0 \cdot 05)$ in female sheep than males, although there was no effect of GDX (Table 1). Basal cAMP production was higher $(P<0.05)$ in cultures from male sheep (Table 1), but not different between the animals of different gonadal status. $\mathrm{ACTH}_{1-24}$-induced increases in cAMP production, relative to basal production, were not different between cultures from male or female, or gonad-intact and GDX sheep (Fig. 4). Basal cortisol production was highest in adrenal cultures derived from gonad-intact male sheep, being significantly $(P<0 \cdot 05)$ greater from these cultures than those from either gonad-intact females or GDX males (Table 1). Basal cortisol production from the cultures obtained from GDX females was not different from that of any other group. Overall, the relative increase in cortisol production in response to $\mathrm{ACTH}_{1-24}$ was greater $(P=0.05)$ in cultures from female than male sheep, and tended $(P=0 \cdot 06)$ to be greater in cultures from gonad-intact compared with GDX animals of both sexes (Fig. 5). In all groups of animals, $\mathrm{ACTH}_{1-24}$ induced 
Table 1 Differences in adrenal weight, basal pituitary ACTH secretion and basal adrenal cortisol and cAMP production in intact and GDX male and female sheep

\begin{tabular}{|c|c|c|c|c|}
\hline & Intact female & GDX female & Intact male & GDX male \\
\hline $\begin{array}{c}\text { Basal ACTH secretion } \\
(\mathrm{pg} / \mathrm{ng} \mathrm{DNA})^{\mathrm{A}}\end{array}$ & $\begin{array}{c}24 \cdot 1 \pm 4 \cdot 0 \\
\quad(n=4)\end{array}$ & $\begin{array}{c}24 \cdot 6 \pm 2 \cdot 4 \\
\quad(n=5)\end{array}$ & $\begin{array}{c}15 \cdot 6 \pm 4 \cdot 4 \\
(n=3)\end{array}$ & $\begin{array}{l}7 \cdot 3 \pm 1 \cdot 7 \\
(n=4)\end{array}$ \\
\hline $\begin{array}{l}\text { Left adrenal mass } \\
\qquad(\mathrm{mg} / \mathrm{kg} \text { body weight })^{\mathrm{A}}\end{array}$ & $\begin{array}{c}44 \cdot 3 \pm 3 \cdot 9 \\
(n=4)\end{array}$ & $\begin{array}{c}48 \cdot 5 \pm 3 \cdot 2 \\
\quad(n=5)\end{array}$ & $\begin{array}{c}32 \cdot 4 \pm 3 \cdot 7 \\
\quad(n=3)\end{array}$ & $\begin{array}{c}40 \cdot 7 \pm 3 \cdot 2 \\
\quad(n=4)\end{array}$ \\
\hline $\begin{array}{l}\text { Basal cortisol production } \\
\text { (ng/ng DNA) }\end{array}$ & $\begin{array}{l}7 \cdot 4 \pm 0 \cdot 7^{\mathrm{a}} \\
(n=4)\end{array}$ & $\begin{array}{l}8 \cdot 4 \pm 0 \cdot 6^{a, b} \\
(n=4)\end{array}$ & $\begin{array}{c}10 \cdot 4 \pm 0 \cdot 4^{\mathrm{b}} \\
(n=3)\end{array}$ & $\begin{array}{l}7 \cdot 5 \pm 0 \cdot 8^{a} \\
(n=4)\end{array}$ \\
\hline $\begin{array}{l}\text { Basal cAMP production } \\
(\mathrm{pmol} / \mathrm{ng} \text { DNA })^{\mathrm{B}}\end{array}$ & $\begin{array}{c}0 \cdot 54 \pm 0 \cdot 05 \\
(n=4)\end{array}$ & $\begin{array}{c}0 \cdot 59 \pm 0 \cdot 07 \\
(n=4)\end{array}$ & $\begin{array}{c}0.94 \pm 0.08 \\
(n=3)\end{array}$ & $\begin{array}{l}0 \cdot 76 \pm 0 \cdot 07 \\
\quad(n=4)\end{array}$ \\
\hline
\end{tabular}

A Significant effect of sex on this parameter $(P<0 \cdot 05)$, with females being greater.

${ }^{B}$ Significant effect of sex on this parameter $(P<0 \cdot 05)$, with males being greater.

${ }^{a}$ and ${ }^{b}$ show the statistical significance of interaction between the sex and gonadal status of the

animals; values which do not share a superscript are significantly different $(P<0 \cdot 05)$ from each other.
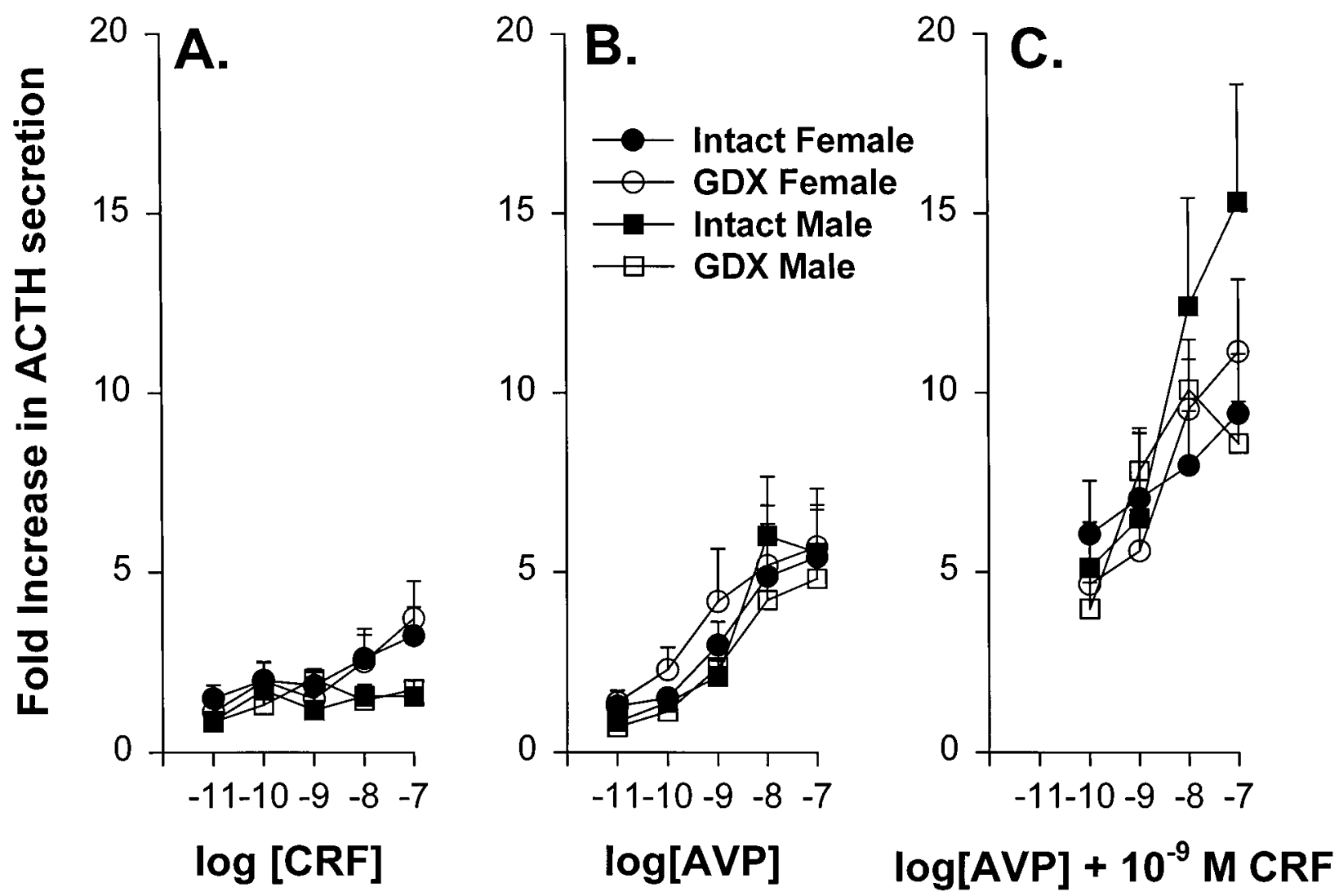

Figure $3 \mathrm{ACTH}$ secretion from anterior pituitary cultures from intact female $(n=4)$, GDX female $(n=5)$, intact male $(n=3)$ and GDX male $(n=3)$ sheep, in response to ovine CRF (A), AVP $(B)$, or AVP in the presence of CRF $\left(10^{-9} \mathrm{M}\right)(\mathrm{C})$, expressed as a ratio of the basal ACTH secretion in individual cultures. The sex or presence of gonads had no effect on the ACTH secretory response to any secretagogue.

concentration-dependent increases $(P<0 \cdot 001)$ in cortisol production (Fig. 5). The relative increase in cortisol production in response to $8 \mathrm{BrcAMP}$ was greater $(P<0 \cdot 05)$ in cultures from female sheep, but there were no significant effects of the GDX on the ability of 8BrcAMP to induce cortisol production (Fig. 6).

\section{Discussion}

We have shown that there are differences between female and male sheep at all levels of the HPA axis, and that long-term GDX can have various effects on the differences between the sexes. These findings represent, to our 


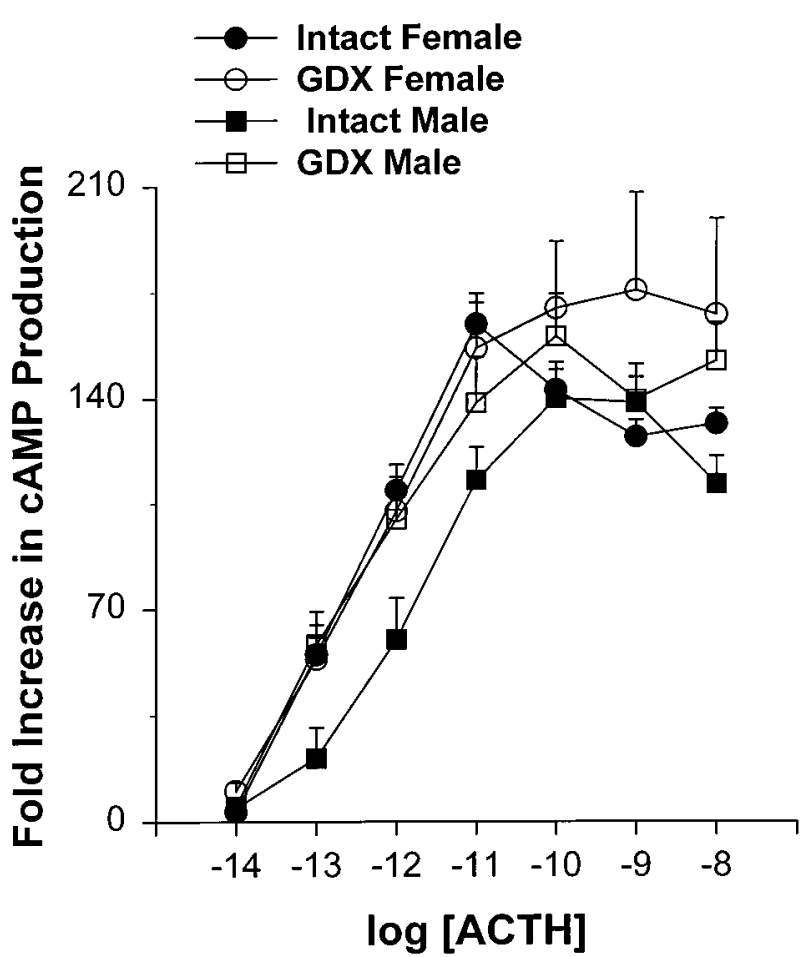

Figure 4 Increases in cAMP production above basal by sheep adrenal cortical cultures in intact female $(n=4)$, GDX female $(n=4)$, intact male $(n=3)$ and GDX male $(n=4)$ sheep in response to ACTH. There was no significant effect of the sex or gonadal status of the animal from which the culture was derived on cAMP production.

knowledge, the first comparison of the effects of both sex and gonadal status on stimulated secretion in vitro of ACTH by the anterior pituitary cells and cortisol production by adrenocortical cells, and suggest that sex differences exist at the level of the adrenal gland but not the pituitary gland. Our observations that adrenocortical cells of female animals have a greater steroidogenic potential and that this increase appears to occur at a post-receptor level, extend the findings of increased adrenal function in females of a number of other species (for review see Handa et al. 1994, El-Migdadi et al. 1995, Nowak et al. 1995). AVP and CRF concentration in the median eminence, anterior pituitary POMC mRNA concentration and basal ACTH secretion in vitro, and basal adrenocortical cell cortisol and cAMP production, were variously affected by sex and GDX, and these observations reinforce the value of examining a number of levels of the HPA axis and the complex regulation of this system.

The concentration of both AVP and CRF in the median eminence was influenced by GDX, and in the case of AVP differences existed between male and female animals. AVP concentrations were found to be higher in males, and also following GDX. These findings are consistent with some, but not all observations, in other

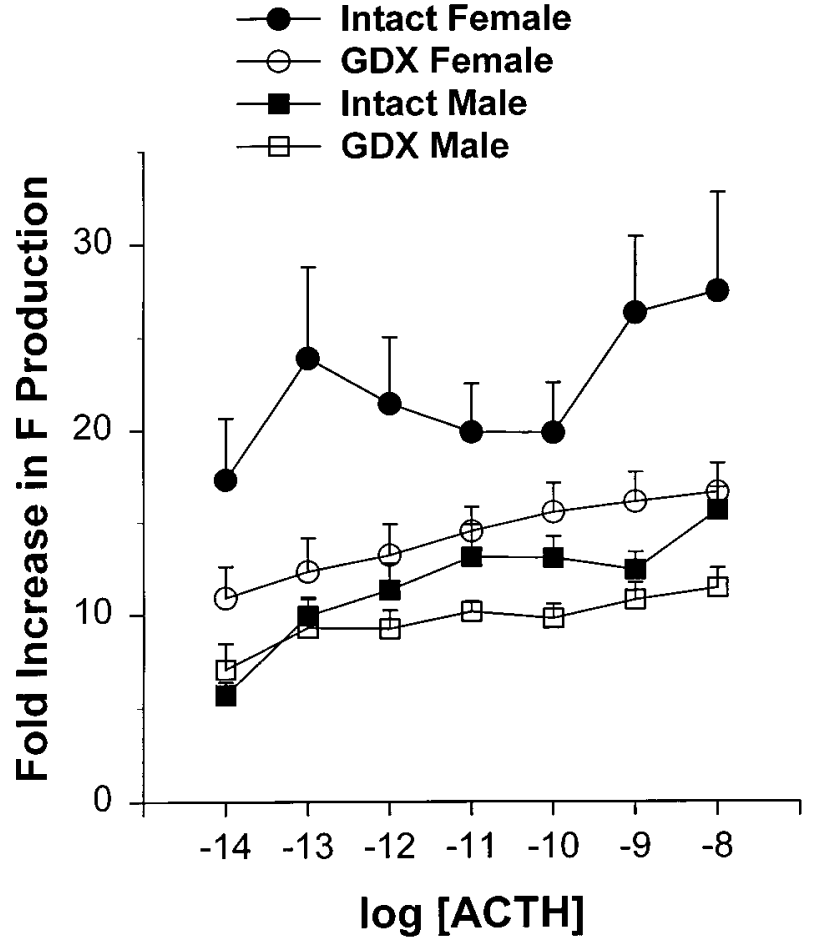

Figure 5 ACTH-induced increases in cortisol (' $\left.\mathrm{F}^{\prime}\right)$ production above basal in adrenal cortical cultures of intact female $(n=4)$, GDX female $(n=4)$, intact male $(n=3)$ and GDX male $(n=4)$ sheep. Cortisol production was greater in cultures from female sheep $(P=0.05)$ than male sheep, and tended to be greater in cultures from intact sheep $(P=0 \cdot 06)$ than GDX sheep.

species. While some studies have shown no effect of sex or gonadal status on hypothalamic AVP mRNA concentrations or the number of AVP-immunoreactive neurones in the rat (Crowley \& Amico 1993, Bingaman et al. 1994, Chisari et al. 1995, Patchev et al. 1995), it has been shown that median eminence AVP concentrations are higher in vehicle-treated GDX male rats when compared with testosterone-replaced animals (Viau \& Meany 1996). In contrast, testosterone may have a stimulatory effect on the number of AVP neurones in the hypothalamus of rats and pigs (van Eerdenburg et al. 1991, De Vries et al. 1994). The reason for the difference in the findings of these studies is not readily apparent, though variations in the physiological state of the animals may play a role. It has been demonstrated that while GDX per se did not affect the concentration of AVP mRNA in male or female rat hypothalami, the presence of sex steroids was essential to allow the normal increase in expression seen in response to an increase in plasma osmolarity (Crowley \& Amico 1993).

It is also clear that the gonads can regulate the levels of CRF in the hypothalamus, though the effect again appears to depend upon the specific experimental paradigm. The human CRF gene has putative oestrogen 


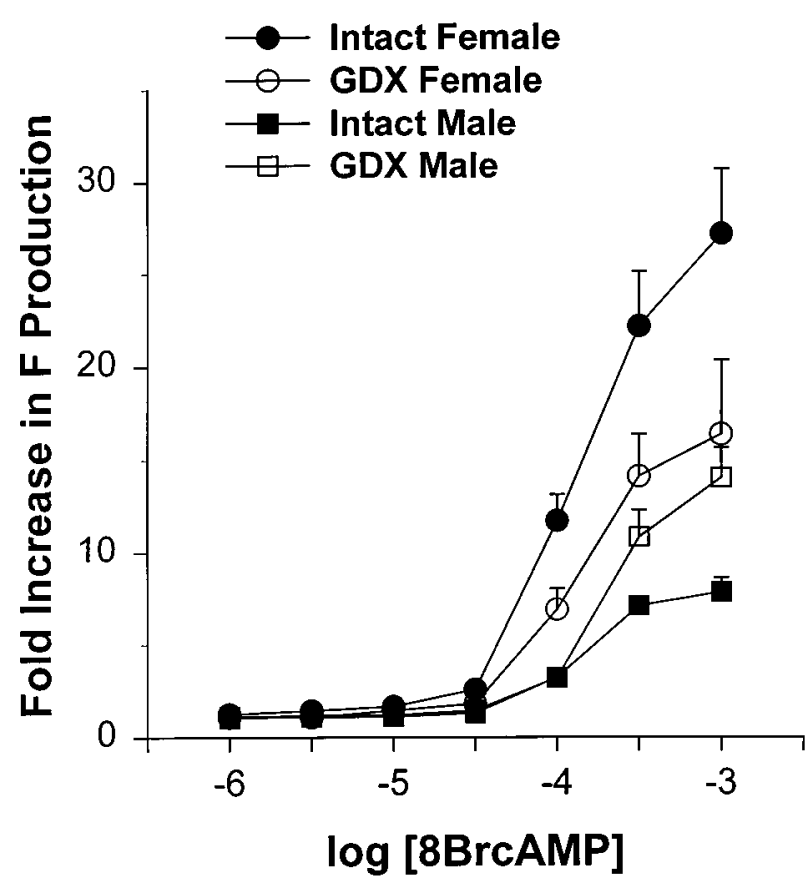

Figure 6 8BrcAMP-induced increases in cortisol (' $F$ ') production above basal in adrenal cortical cultures of intact female $(n=4)$, GDX female $(n=4)$, intact male $(n=3)$ and GDX male $(n=4)$ sheep. Cortisol production was greater in cultures from female sheep $(P<0 \cdot 05)$ than male sheep, but there was no effect of the gonadal status of the animal from which the culture was derived.

response elements in the $5^{\prime}$ promoter region, and these have been associated with an increase in CRF gene expression by oestradiol in vitro (Vamvakopoulos \& Chrousos 1993, Paulmyer-Lacroix et al. 1996). The effects of oestradiol in vivo on CRF expression, however, appear to depend on complex interactions involving adrenal glands. Paulmyer-Lacroix et al. (1996) have shown that oestradiol treatment in vivo inhibits CRF expression in intact rats, but increases the expression in adrenalectomised animals. These observations most probably reflect the fact that oestradiol has stimulatory actions on adrenal glucocorticoid production (vide infra), which, in turn, will inhibit CRF production (Vamvakopoulos \& Chrousos 1994, Jingami et al. 1985). The effects of testosterone, as deduced from experiments involving GDX and/or in vivo replacement regimens, on hypothalamic CRF appear somewhat variable. Inhibitory (Haas \& George 1988, Bingaman et al. 1994) or no effects (Almeida et al. 1992, Shanks et al. 1994, Hadid et al. 1995, Viau \& Meaney 1996) of testosterone on CRF neurones have both been reported, without any clear explanation of the differences between the studies. In the specific case of the sheep, CRF mRNA content in the paraventricular nucleus is not altered during pregnancy, lactation or exogenous oestradiol and progesterone treatment of the female sheep (Broad et al. 1995). The amount of CRF mRNA was elevated immediately after parturition, though it is not clear if this was due to changing levels of gonadal steroids or a reflection of the stress of parturition. While it has been argued that the CRF gene represents an important point of regulation of the sexual dimorphism of the HPA axis (Vamvakopoulos \& Chrousos 1993), the available evidence does not unequivocally support this contention.

The content of POMC mRNA was greater in the anterior pituitaries of intact males than intact females, with GDX animals of both sexes having intermediate levels of POMC mRNA. There is a substantial literature describing the regulation of POMC mRNA in the hypothalamus by gonadal steroids, but few reports of the anterior pituitary exist. In the hypothalamus of the rat, oestradiol and testosterone have variable effects on POMC expression (Wilcox \& Roberts 1985, Blum et al. 1989, Chowen-Breed et al. 1989), which appear to depend upon the precise anatomical location that is being studied. In a study of male sheep, testosterone decreased POMC mRNA levels in some, but not all, hypothalamic sites (Hileman et al. 1996). In ewes, no difference in anterior pituitary POMC mRNA was reported between intact and GDX animals (Mercer et al. 1989), while progesterone and oestradiol treatment appeared to increase anterior pituitary POMC mRNA (Whisnant et al. 1992) in GDX ewes. Our present observations may be at odds with a number of studies which report higher ACTH content in the anterior pituitaries of female rats (Lesniewska et al. 1990, Chisari et al. 1995), though it is not clear if such differences reflect the species studied, or the methodology (mRNA vs peptide content) employed. It is worth noting in the present study, that basal ACTH secretion was greater from the cultures of the anterior pituitary cells of female animals, and this parameter may be a better reflection of anterior pituitary ACTH content.

The sex or gonadal status of the animals from which anterior pituitary cultures were derived had no effect on ACTH secretion in response to CRF, AVP or their combination. As has been previously reported (Familari et al. 1989), AVP alone is a more potent ACTH secretagogue than is CRF alone, in sheep anterior pituitary cultures, and this order of effectiveness was not altered by differing sex or gonadal status. AVP has also been reported to be an effective in vivo ACTH secretagogue in the sheep (Smith et al. 1989, Pecins-Thompson \& Keller-Wood 1994), though these findings have been recently called into dispute (McFarlane et al. 1995). A number of previous studies have examined the in vitro ACTH responses of anterior pituitaries from rats of the two sexes and various gonadal statuses to a range of ACTH secretagogues, and these have also been unable to elucidate any differences (Hary et al. 1993, Handa et al. 1994).

At the level of the adrenal gland, the most striking difference observed was that cortisol production in 
response to both $\mathrm{ACTH}$ and $8 \mathrm{BrcAMP}$ was greater from cultures of female animals, with GDX appearing to have little effect. This observation is consistent with an extensive and long-standing in vivo literature which demonstrates that the female adrenal cortex produces more glucocorticoids than does the male, an effect which has been attributed to the stimulation of the adrenal gland by oestradiol (Kitay 1961, Coyne \& Kitay 1969, for review see Handa et al. 1994). In contrast, it does not appear in the sheep that oestradiol is the single regulator of adrenocortical responsiveness, as the effect of long-term GDX on either ACTH- or 8BrcAMP-induced cortisol production was the same in both sexes. Somewhat surprising, however, was our observation that basal cortisol production was greatest by cells derived from intact male sheep. This finding differs from a number of previous studies (Vinson et al. 1978, Lesniewska et al. 1990, Wiesenfeld \& Michaelis 1994), where glucocorticoid production from female animals appears to be greater under basal conditions. In two studies examining basal cortisol production by sheep foetuses, one found increased production by females (Ayromlooi \& Essman 1978), while the other suggested that males produced more cortisol (Schwartz \& Rose 1998). The in vitro production of cortisol by adrenocortical cells from female sheep was greater by cells from late-pregnant ewes than by cells from non-pregnant ewes (Glickman et al. 1980), and it is possible that the relatively oestrogenic environment of late pregnancy underlies this difference.

Our observation that both ACTH and 8BrcAMP induce greater cortisol production in cultures from female animals suggests that the differences in adrenocortical cells occurs distal to the production of cAMP, which is considered the principal intercellular mediator of ACTH action at the adrenal (Simpson \& Waterman 1988). Consistent with this notion is our observation that stimulated cAMP production was not affected by sex or GDX. The expression or activity of a number of steroidogenic enzymes in the adrenal has been reported to be increased in females, compared with males, or stimulated by oestrogens and inhibited by androgens (Belanger et al. 1991, Gallant et al. 1991, Perry \& Stalvey 1992, Issacson et al. 1993, ElMigdadi et al. 1995, Nowak et al. 1995). The observation of increased steroidogenic potential in the female may, however, be somewhat secretagogue-specific, as we have recently shown that AII-induced cortisol production is greater in adrenocortical cultures from intact male sheep, than it is in GDX male or intact female sheep (Canny et al. 1998).

In conclusion, the results of this study have demonstrated that significant differences in the HPA axes exist between male and female sheep, and that some of these differences appear to directly depend on gonadal factors. Importantly, isolated adrenocortical cells of female sheep exhibit enhanced steroidogenesis in response to ACTH, and this increase appears to occur at a site following the production of cAMP. This finding confirms, in vitro, the response of many species in vivo, and suggests a specific cellular mechanism of action. These observations therefore provide a model system to further investigate the differences between the HPA axes of male and female animals.

\section{Acknowledgements}

The authors would like to thank Alix Rao, Bruce Doughton, Jodie Bond and Alison Skinner for expert technical assistance. This work was supported by grants from the National Health and Medical Research Council of Australia, and the Monash Research Fund.

\section{References}

Almeida OFX, Hassan AHS, Harbuz MS, Linton EA \& Lightman SL 1992 Hypothalamic corticotropin-releasing hormone and opioid peptide neurons: functional changes after adrenalectomy and/or castration. Brain Research 571 189-198.

Ayromlooi J \& Essman WB 1978 Sex differences in fetal sheep adrenal steroidogenesis. International Journal of Gynaecology and Obstetrics 17 3-5.

Belanger B, Caron S, Boudou P, Fiet J \& Belanger A 1991 Adrenal steroidogenesis in the guinea pig: effects of androgens. Steroids $\mathbf{5 7}$ 76-81.

Bell ME, Wood CE \& Keller-Wood M 1991 Influence of reproductive state on pituitary adrenal function in the ewe. Domestic Animal Endocrinology 8 245-254.

Bethea CL, Brown NA \& Kohama SG 1996 Steroid regulation of estrogen and progestin receptor messenger ribonucleic acid in monkey hypothalamus and pituitary. Endocrinology 137 4372-4383.

Bingaman EW, Magnuson DJ, Gray TS \& Handa RJ 1994 Androgen inhibits the increases in hypothalamic corticotropin-releasing hormone $(\mathrm{CRH})$ and $\mathrm{CRH}$-immunoreactivity following gonadectomy. Neuroendocrinology 59 228-234.

Blum M, Roberts JL \& Wardlaw SL 1989 Androgen regulation of proopiomelanocortin gene expression and peptide content in the basal hypothalamus. Endocrinology 124 2283-2288.

Bocking AD, McMillen IC, Harding R \& Thorburn GD 1986 Effect of reduced uterine blood flow on fetal and maternal cortisol. Journal of Developmental Physiology 8 237-245.

Bremner WJ, Cumming IA, Winfield CG, de Kretser DM \& Galloway DB 1984 A study of the reproductive performance of mature Romney and Merino rams throughout the year. In Reproduction in Sheep, vol 1, pp 16-17. Eds DR Lindsay \& DT Pearce. Canberra: Australian Academy of Science and Australian Wool Corporation.

Broad KR, Keverne EB \& Kendrick KM 1995 Corticotrophin releasing factor mRNA expression in the sheep brain during pregnancy, parturition and lactation and following exogenous progesterone and oestrogen treatment. Brain Research. Molecular Brain Research 29 310-316.

Canny BJ, O’Farrell KA, Clarke IJ \& Tilbrook AJ 1998 Angiotensin II- and phorbol ester-induced steroidogenesis on ovine adrenocortical cells: effect of sex and the gonadal status of the donor animal. Clinical and Experimental Pharmacology and Physiology 25 401-404.

Carey MP, Deterd CH, de Koning J, Helmerhorst F \& de Kloet ER 1995 The influence of ovarian steroids on hypothalamic-pituitaryadrenal regulation in the female rat. Journal of Endocrinology 144 $311-321$. 
Chisari A, Carino M, Perone M, Gaillard RC \& Spinedi E 1995 Sex and strain variability in the rat hypothalamo-pituitary-adrenal (HPA) axis function. Journal of Endocrinological Investigation 18 25-33.

Chowen-Breed J, Fraser HM, Vician L, Damassa DA, Clifton DK \& Steiner RA 1989 Testosterone regulation of proopiomelanocortin messenger ribonucleic acid in the arcuate nucleus of the male rat. Endocrinology 124 1697-1702.

Coyne MD \& Kitay JI 1969 Effect of ovariectomy on pituitary secretion of ACTH. Endocrinology 85 1097-1102.

Crowley RS \& Amico JA 1993 Gonadal steroid modulation of oxytocin and vasopressin gene expression in the hypothalamus of the osmotically stimulated rat. Endocrinology 133 2711-2718.

Da Silva JAP 1995 Sex hormones, glucocorticoids and autoimmunity: facts and hypotheses. Annals of the Rheumatic Diseases 54 6-16.

De Vries GJ, Wang Z, Bullock NA \& Numan S 1994 Sex differences in the effects of testosterone and its metabolites on vasopressin messenger RNA levels in the bed nucleus of the stria terminalis of rats. Journal of Neuroscience 14 1789-1794.

van Eerdenburg FJCM, Lugard-Kok CMJE, Dieleman SJ, Bevers MM \& Swaab DF 1991 Influence of gonadectomy and testosterone supplementation on the postnatal development of the vasopressin and oxytocin-containing nucleus of the pig hypothalamus. Neuroendocrinology 54 580-586.

El-Migdadi F, Gallant S \& Brownie AC 1995 Sex differences in cytochrome oxidase and $\mathrm{P}-450_{11 \beta}$ in the rat adrenal cortex. Molecular and Cellular Endocrinology 112 185-194.

Familari M, Smith AI, Smith R \& Funder JW 1989 Arginine vasopressin is a much more potent stimulus to ACTH release from ovine anterior pituitary cells than ovine corticotropin-releasing factor. I In vitro studies. Neuroendocrinology 50 152-157.

Gallant S, Alfano J, Charpin M \& Brownie AC 1991 Expression of adrenal cytochromes $\mathrm{P}-450$ in testosterone-induced hypertension. Hypertension 18 523-528.

Gallucci WT, Baum A, Laue L, Rabin DS, Chrousos GP, Gold PW \& Kling MA 1993 Sex differences in the sensitivity of the hypothalamo-pituitary-adrenal axis. Health Psychology 12 420-425.

Gaskin JH \& Kitay JI 1970 Adrenocortical function in the hamster: sex differences and effects of gonadal hormones. Endocrinology 87 779-786.

Glickman JA, Patrick JE \& Challis JRG 1980 Increase in the response to adrenocorticotrophin of isolated maternal adrenal cells from sheep in late pregnancy. Journal of Endocrinology 86 93-100.

Haas DA \& George SR 1988 Gonadal regulation of corticotropinreleasing factor immunoreactivity in hypothalamus. Brain Research Bulletin 20 361-367.

Hadid R, Spinedi E, Daneva T, Grau G \& Gaillard RC 1995 Repeated endotoxin treatment decreases immune and hypothalamo-pituitary-adrenal axis responses: effects of orchidectomy and testosterone therapy. Neuroendocrinology 62 348-355.

Handa RJ, Nunley KM, Lorens SA, Louie JP, McGivern RF \& Bollnow MR 1994 Androgen regulation of adrenocorticotropin and corticosterone secretion in the male rat following novelty and foot shock stressors. Physiology and Behavior 55 117-124.

Hary L, Dupouy LP \& Chatelain A 1993 ACTH secretion from isolated anterior lobes of male and female newborn rats: effects of corticotrophin-releasing factor, arginine vasopressin and oxytocin alone and in combination. Journal of Endocrinology 137 123-132.

Herbison AE 1995 Neurochemical identity of neurones expressing oestrogen and androgen receptors in sheep hypothalami. Journal of Reproduction and Fertility (Suppl) 49 271-283.

Hileman SM, Lubbers LS, Petersen SL, Kuehl DE, Scott CJ \& Jackson GL 1996 Influence of testosterone on LHRH release, LHRH mRNA and pro-opiomelanocortin mRNA in male sheep. Journal of Neuroendocrinology 8 113-121.

Hirst JJ, West NB, Brenner RM \& Novy MJ 1992 Steroid hormone receptors in the adrenal glands of fetal and adult rhesus monkeys. Journal of Clinical Endocrinology and Metabolism 75 308-314.
Issacson WK, Jones SJ \& Kreuger RJ 1993 Testosterone, dihydrotestosterone, trenbolone acetate and zeronal alter the synthesis of cortisol in bovine adrenocortical cells. Journal of Animal Science 71 1771-1777.

Jingami H, Matsukara S, Numa S \& Imura H 1985 Effects of adrenalectomy and dexamethasone administration on the level of prepro-corticotropin-releasing factor messenger ribonucleic acid (mRNA) in the hypothalamus and adrenocorticotropin/betalipotropin precursor mRNA in the pituitary in rats. Endocrinology 117 1314-1320.

Keller-Wood M \& Wood CE 1991 Effect of ovariectomy on vasopressin, $\mathrm{ACTH}$ and renin activity responses to hypotension. American Journal of Physiology 261 R223-R230.

Kitay JI 1961 Sex differences in adrenal cortical secretion in the rat. Endocrinology 68 818-824.

Labarca C \& Paigen K 1980 A simple, rapid and sensitive DNA assay procedure. Analytical Biochemistry 102 344-352.

Lesniewska B, Nowak M \& Malendowicz LK 1990 Sex differences in adrenocortical structure and function. XXVIII. ACTH and corticosterone in intact gonadectomised and gonadal hormone replaced rats. Hormone and Metabolic Research 22 378-381.

MacLusky NJ, Yuan H, Elliott J \& Brown TJ 1996 Sex differences in corticosteroid binding in the rat brain: an in vitro autoradiographic study. Brain Research 708 71-81.

McFarlane A, Coghlan J, Tresham J \& Wintour EM 1995 Corticotrophin-releasing factor alone, but not arginine vasopressin alone, stimulates the release of adrenocorticotropin in the conscious intact sheep. Endocrinology 136 1821-1827.

Madigou T, Tiffoche C, Lazannec G, Pelletier J \& Thieulant ML 1996 The sheep estrogen receptor: cloning and regulation of expression in the hypothalamo-pituitary axis. Molecular and Cellular Endocrinology 121 153-163.

Marley PD, Thomson KA, Jachno K \& Johnston MJ 1991 Histamineinduced increases in cyclic AMP levels in bovine adrenal medullary cells. British Journal of Pharmacology 104 839-846.

Mercer JE, Clements JA, Clarke IJ \& Funder JW 1989 Glucocorticoid regulation of proopiomelanocortin gene expression in the pituitary gland of hypothalamo-pituitary intact and hypothalamo-pituitary disconnected sheep. Neuroendocrinology 50 280-285.

Nowak KW, Neri G, Nussdorfer GG \& Maledowicz LK 1995 Effects of sex hormones on the steroidogenic activity of dispersed adrenocortical cells of the rat adrenal cortex. Life Sciences $\mathbf{5 7}$ 833-837.

Patchev VR, Hayashi S, Orikasa C \& Almeida OFX 1995 Implication of estrogen-dependent brain organization for gender differences in hypothalamo-pituitary-adrenal regulation. FASEB Journal 9 419-423.

Paulmyer-Lacroix O, Héry M, Pugeat M \& Grino M 1996 The modulatory role of estrogens on corticotropin-releasing factor gene expression in the hypothalamic paraventricular nucleus of ovariectomised rats: role of the adrenal gland. Journal of Neuroendocrinology 8 515-519.

van der Pavert SA, Clarke IJ, Rao A, Vrana KE \& Schwartz J 1997 Effects of vasopressin and elimination of corticotropin-releasing hormone-target cells on pro-opiomelanocortin mRNA levels and adrenocorticotropin secretion in ovine anterior pituitary cells. Journal of Endocrinology 154 139-147.

Pecins-Thompson M \& Keller-Wood M 1994 Prolonged absence of ovarian hormones in the ewe reduces the adrenocorticotropin response to hypotension, but not to hypoglycemia or corticotropin-releasing factors. Endocrinology 134 678-684.

Perry JE \& Stalvey JRD 1992 Gonadal steroids modulate adrenal fasciculata $3 \beta$-hydroxysteroid dehydrogenase-isomerase activity in mice. Biology of Reproduction 46 73-82.

Roelfsma F, van den Berg G, Frolich M, Veldhuis JD, van Eijk A, Buurman MM \& Etman BH 1993 Sex dependent alteration in cortisol response to endogenous adrenocorticotropin. Journal of Clinical Endocrinology and Metabolism 77 234-240. 
Schwartz J \& Rose JC 1998 Development of the pituitary adrenal axis in fetal sheep twins. American Journal of Physiology 274 R1-R8.

Shanks N, McCormick CM \& Meaney MJ 1994 Sex differences in the hypothalamic-pituitary-adrenal responding to endotoxin challenge in the neonate: reversal by gonadectomy. Brain Research. Developmental Brain Research 79 260-266.

Simpson ER \& Waterman MR 1988 Regulation of the synthesis of steroidogenic enzymes in adrenal cortical cells by ACTH. Annual Review of Physiology $\mathbf{5 0}$ 427-440.

Smith AI, Familari M, Wallace CA, Smith R, Schwartz J, Canny BJ, Pham T, Clarke IJ \& Funder JW 1989 Differential regulation in the hypothalamo-pituitary-adrenal axis. In The Adrenal and Hypertension: From Cloning to Clinic, vol 57 Serono Symposia Publications, pp 243-258. Ed. F Mantero. New York: Raven Press.

Turner BB \& Weaver DA 1985 Sexual dimorphism of glucocorticoid binding in rat brain. Brain Research 343 16-23.

Vamvakopoulos NC \& Chrousos GP 1993 Evidence of direct estrogenic regulation of human corticotropin-releasing hormone gene expression: potential implications for the sexual dimorphism of the stress response and immune/inflammatory reaction. Journal of Clinical Investigation 92 1896-1902.

Vamvakopoulos NC \& Chrousos GP 1994 Hormonal regulation of human corticotropin-releasing hormone gene expression: implications for the stress response and immune/inflammatory reaction. Endocrine Reviews 15 409-420.
Viau V \& Meany MJ 1996 The inhibitory effect of testosterone on hypothalamic-pituitary-adrenal responses to stress is mediated by the medial preoptic area. Journal of Neuroscience 16 1866-1876.

Vinson GP, Whitehouse BJ \& Goddard C 1978 The effect of sex and strain of rats on the in vitro response of adrenocortical tissue to ACTH stimulation. Journal of Steroid Biochemistry $9553-560$.

Whisnant CS, Curto K \& Goodman RL 1992 Immunocytochemical localization of beta endorphin and gonadal steroid regulation of proopiomelanocortin messenger ribonucleic acid in the ewe. Neuroendocrinology 56 812-821.

Wiesenfeld P \& Michaelis OE 1994 Gender differences in adrenal cortex steroid production in SHR/N corpulent rats. Proceedings of the Society for Experimental Biology and Medicine 207 254-259.

Wilcox JN \& Roberts JL 1985 Estrogen decreases rat hypothalamic proopiomelanocortin messenger ribonucleic acid levels. Endocrinology 117 2392-2396.

Young EA 1995 The role of gonadal steroids in hypothalamicpituitary-adrenal axis regulation. Critical Reviews in Neurobiology 9 371-381.

Received 3 September 1998

Accepted 8 March 1999 